\title{
Effective Strategies for Hiring Employees Despite Social Affiliation \\ Gholston, Sylvia
}

Chattahoochee Technical College, GA, United States

Doi:10.5901/ajis.2015.v4n2p211

\section{Abstract}

This literature review study was to explore information from multiple authors and studies on Effective Strategies for Hiring Employees Despite Social Affiliation in order to aid management best practices in businesses. The lack of strategies highlighted the uncertainty in the hiring processes for businesses. The significance of this study, which is to provide strategies for hiring managers could encourage effective hiring practices. Strategic hiring practices could encourage business leaders to develop sound hiring systems that could benefit both the companies and the community in which these businesses operate.

Keywords: Social Identity Theory; Expectancy Theory; Decision Making, Social Affiliation

\section{Conceptual Framework Concepts on Hiring Employees}

Three theories proffer a framework for this literature study that includes the concepts of social identity theory, expectancy theory, and decision field theory. These theories and concepts aid in forming the basis of this study's subject relating to strategies for hiring the best candidate despite social affiliation. The principles provided by the components of these concepts contribute to the subject of determining strategies for hiring managers in the Metro Atlanta Georgia area. The context of the concepts as shown in Figure 1 highlights the requirement of tactics for efficient strategies in hiring employees.

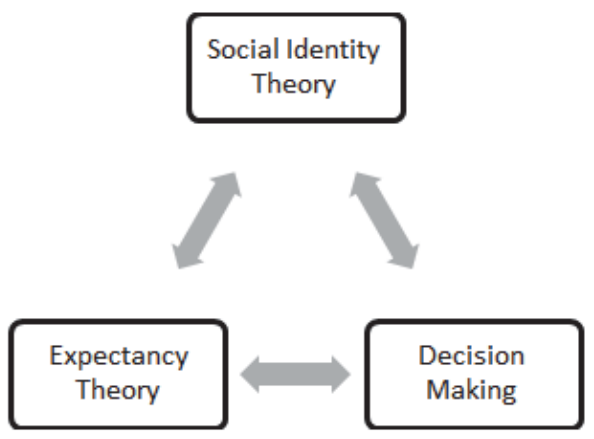

Figure 1: Conceptual framework of the study.

The achievement of this literature review stemmed from the review of hiring documents and an evaluation of published materials to determine a successful approach for addressing the hiring concerns. In addition, the research review aids with determining strategies for members of management requiring effective hiring techniques in the Metro Atlanta, Georgia area. Hiring employees is an important practice conducted within businesses (Rehman, 2012). Improper hiring increases business cost, turnover, and decreases employee moral (Poddar \& Madupalli, 2012). This literature review contains information from multiple authors based on the aspects of the conceptual framework, which are social identity theory, expectancy theory, and decision making. 

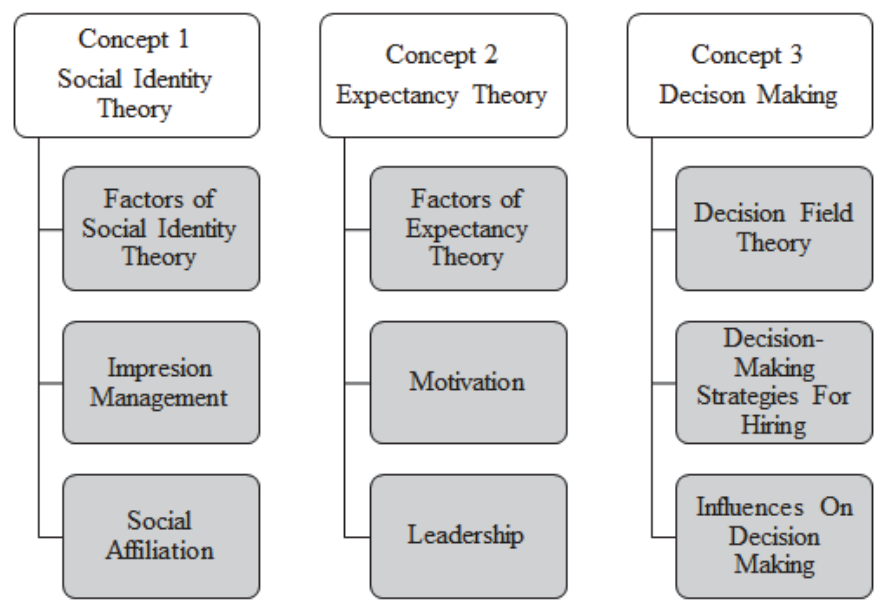

Figure 2: Organization and subsections of the concepts within the literature review.

\section{Social Identity Theory}

Individuals distinguish themselves based on the groups they affiliate (Tajel, 1979). One chief notion of the social identity theory is that individuals tend to relate to groups in which they share more than the same beliefs. Tajel and Turner (1986) and Pearce (2013) found that a group establishes itself when three or more individuals assess themselves in terms of common qualities, principles, standards based on beliefs, backgrounds, culture, or group affiliation creating in-groups. Tajel and Turner (1986) and Liu, Friedman, and Hong (2012) continued and explained how these in-groups separate themselves from people not meeting these common qualities or out-groups. Individuals utilize social identity theory as a means of obtaining goals and increasing self-confidence (Hewapathirana, 2011).

\subsection{Factors of social identity theory}

People become members of social groups, which is a group of three or more people that maintain the same beliefs and share a similar social identity. Identification is important for a person because identity becomes an individual's perception of reality (Smith, Amiot, Callan, Terry, \& Smith, 2012). Due to this reality, people feel the need to work and associate with others that share that identity. Although individuals share the same identity, researchers found that group members choose to maintain a positive identity (Walumbwa et al., 2011). Walumbwa et al. (2011) also determined that social identity aids with gaining power and feeling increased self-esteemed. Conversely, Smith et al., (2012) suggested that social identity highlights issues such as stereotyping and bias. Furthermore, people that choose their social identities as a means of belonging to certain groups, use these memberships for personal gain (Smith et al., 2012).

Smith et al. (2012) conducted research to examine the connection between social identity and organizational commitment. The researchers used the concept of social identity theory for insight into exploring the actions of people. Social identity theory originated as a theory focusing on an individual's view of themselves and their contribution to an organization. When a person identifies with a group, that individual achieves a social identity and increased confidence (Hewapathirana, 2011). The researcher suggested that there is a common thread between an individual's identity within a group and the commitment within the group (Hewapathirana, 2011). Once an individual commits to the group, he or she adopts the values and strategies for that group (Hewapathirana, 2011). This is helpful within a business because if a newly hired employed identifies with the members of the organization, the worker may stay with the company for an extended period.

As the concept has evolved, researchers such as Ashforth and Mael (1989) examined social identity theory to determine if members of groups have a connection with the accomplishments and failures of the organizations that employ them. Managers should understand the importance of social identity in which he or she may identify him or herself and use this identity towards employees (Ashforth \& Mael, 1989). On the other hand, the social identity of a manager can stem from the organization as well as other entities outside of work that provides a form of affiliation (Ashforth \& Mael, 1989). In addition, when an individual is a member of a group, that person does not need to interact with other members for example, being a sports fans or professional memberships (Ashforth \& Mael, 1989). 
Situations, experiences, and other factors influence the decisions made by individuals. The concept of social identity theory aids with questioning the influences of the in-group versus the out-group (Tajfel \& Turner, 1986). Tajfel and Turner (1986) found that in-group members separate themselves from people that do not meet the common qualities or the out-group. The idea of in-group connections and affiliation potentially overshadowing an individuals' ability to become unique and make decisions without influence is intriguing to many scholars (Tajfel \& Turner, 1986).

\subsection{Impression management theory}

Impression management has several definitions within the literature; however, each definition depicts the same key components. The foundation of each definition is that an individual engages in actions to affect their image. The perspective of the researcher or the purpose of the research determines the multiple meanings of impression management. The communal definition of impression management is the methods or avenues a person attempts in order to control the impression others have of them (Uziel, 2010). Uziel (2010) determined that a facet of impression management is social desirability. Researchers use social desirability interchangeably with impression management yet refers to responses used by participants during the research process to display a good image of themselves (Uziel, 2010). Conversely, Leary and Kowalski (1990) determined that a facet of impression management is self-presentation. The researchers use impression management and self-presentation interchangeably; however, actors of self-presentation manage the images of companies and workers (Leary \& Kowalski, 1990).

Uziel (2010) divided impression management into two categories the defensiveness approach and the adjustment approach. Scholars determined that the defensiveness approach is when individuals use defensive self-presentation. Scholars determined that the adjustment approach is an approach used by individuals to reflect adjustments with behaviors.

Kleinmann and Klehe (2011) determined through research that within organizations, individuals use impression management during the hiring process. The forms of impression management used during the interview process are assertive and defensive behavior (Kleinmann \& Klehe, 2011). For assertive impression management, the interviewee uses cues within the environment, from the hiring manager to aid with the using the managers perceptions to provide correct responses. In addition to correct responses, using impression management during the hiring process aids applicants with self-promotion and creating a favorable outlook during the interview (Kleinmann \& Klehe, 2011). For defensive impression management, the interviewee attempts to repair any negative comments or answers provided during the interview process (Kleinmann \& Klehe, 2011). The interviewee accepts responsibility for bad behavior and apologizes for mistakes made (Kleinman \& Klehe, 2011). Based on the research collected the communal factor is that interviewees whether intentional or unintentional use impression management during the interview process.

\subsection{Social affiliation}

Social affiliation is a common term in society. The meaning of social affiliation varies based on the circumstances used. The communal definition of the term social affiliation is a connection or relationship with a group on a social level (Rivera, 2012). This could be educational, religious, professional, and political. Managers have affiliations from their prior and current situations as well as experiences. The concept of social affiliation attracted the attention of researchers to understand the impact this concept has on organizations (Nagy, Kacmar, \& Harris, 2011). Due to the role played in decision making and impact on self and group judgments, understanding affiliation has been an interesting topic in business literature.

Affiliation plays an important role within everyday life. Individuals use affiliations for personal gain, and affiliation helps individuals with a sense of belonging and pride. Company leaders use affiliations to sell products and maintain competitive advantage (Marin \& Ruiz de Maya, 2013). Prior affiliations aid workers with gaining employment (Rider, 2012). On the other hand, prior affiliations aid employees such as CEOs with earning higher wages (Jalbert, Furumo, \& Jalbert. 2011). Educational affiliations could help applicants with getting employment. Obtaining a college degree is becoming a necessity in order to earn employment (Fischer, 2010). Companies recruit and hire employees to complete different work related tasks (Khan, 2013). Some corporations require that potential employees obtain a degree from a college and/or university (Culkin \& Mallick, 2011). Khan (2013) found that university faculty and leaders primarily attempt to prepare students for employment. In addition, depending on the degree earned, some institutional leaders pride themselves on the amount of graduates that earn employment prior to or immediately after graduation (Culkin \& Mallick, 2011). 


\section{Expectancy Theory}

Each day within organizations managers work with employees that rely on the expertise of supervisors for guidance and support to complete tasks (Kochanowski, 2011). Based on the expectancy theory, individuals are motivated due to their intentions and the expectation of those intentions (Vroom, 1964). Within organizations, executive leaders motivate employees for company goal attainment. The decisions of individuals when attempting to attain goals align with expectancy (Fitzsimmons \& Douglas, 2011). Vroom's expectancy theory assumes that individuals expect certain incentives for their actions and there is a distinct relationship between work completed and accomplishment.

\subsection{Factors of expectancy theory}

Vroom's theory of motivation stems on the idea that individuals prefer certain outcomes over others. Employees and executives expect having satisfaction when reaching a goal or job performance outcome. This achievement regardless of satisfaction or not is viewed only by that individual (Vroom, 1964). Through the theory of motivation, Vroom designed the Expectancy Theory. The theory does not provide specific suggestions on the exact catalyst for motivating employees (Lunenburg, 2011). From an executive standpoint, motivation stems from the employees views of workplace outcomes, which in turn depicts the level of work related motivation (Lunenburg, 2011). An executive attempting to motivate a hiring manager should ensure that the outcome of the hiring manager's decisions provides the expected outcome desired. If the outcome of the decision meets the expectation of the hiring manager, that manager could be motivated to continue the work practice (Vroom, 1964).

Three key elements aid with understanding the expectancy theory: expectancy, instrumentality, and valence. The effort required to achieve an outcome describes expectancy (Renko \& Kroeck, \& Bullough, 2012). Conditions that could enhance expectancy include company resources, training, and support from executives. The probability that performance leads to different outcomes describes instrumentality (Renko et al., 2012). Things that could impact instrumentality include having an understanding about performance and outcomes, and trust for company executives. Valence is the strength of preference for a reward (Renko et al., 2012). In terms of valence, the outcome could be negative or positive (Renko et al., 2012). Since valence can be negative or positive, in business valence is often associated with employee bonuses, lower costs, and increasing profits. Based on expectancy theory framework, this study could provide a better understanding about the impact of strategies for motivating hiring managers to hire the best candidate. Within the expectancy theory different variables such as job performance, the motivation of executives, job choice, and pay may be predicted (Liao, Liu, \& Pi, 2011). With this in mind, leaders could try to increase the understanding that workers have the capabilities to complete job tasks, perform well, and work within company procedures will result in rewards (Lunenburg, 2011).

\subsection{Motivation}

A characteristic of an effective leader is the ability to motivate employees. A primary function of business leaders is to motivate and influence employees (Cerasoli, Nicklin, \& Ford, 2014). The two popular forms of motivated behavior are intrinsic motivation and extrinsic motivation (Vallerand, 2012). When a person behaves a certain way for interval value and or satisfaction, this individual is responding to intrinsic motivation (Pierce, Cameron, Banko, \& So, 2012). Conversely, when a person engages in behavior because of external rewards or satisfaction, this individual is responding to extrinsic motivation (Dysvik \& Kuvaas, 2013). External rewards are an effective method for motivating employees. Organizational leaders use financial incentives as a tool for motivating workers (Nawab, Bhatti, \& Shafi, 2011). Motivated employees follow company guidelines and perform better than unmotivated workers (Vallerand, 2012).

Employee motivation could be a possible determinant of worker success. Therefore, if leaders understand the determinants of workers, the organization could gain competitive advantage (Korzynski, 2013). In order to motivate workers successfully, leaders should understand the importance of motivation. The beginning step to understanding the importance is defining motivation. Based on Maslow's (1943) hierarchy of needs, the human motivation process depends on five needs. The needs are (a) physiological, (b) safety, (c) love, (d) esteem, and (e) self-actualization (Maslow, 1943). Maslow's (1943) hierarchy of needs is a common theory used for explaining the process of motivation based on human needs. Vroom's (1964) expectancy theory is similar to the hierarchy of needs. The specific needs of a person could motivate them, but later, that motivation for the same need could change. Leaders should understand the needs of employees as well as understand when the needs change. 
Employee motivation could stem from the environment of the job (Vallerand, 2012). Conversely, Cadwallader et al. (2010) suggested that motivation is more than personality and behavior. When employees are motivated to do their jobs, they become more satisfied with the job and increase their commitment (Khan, Riaz, \& Rashid, 2011). Additionally, highly motivated environments promote a work culture of excellence (Khan et al., 2011). Employee efficiency increases based on the rewards. These rewards can be intrinsic or extrinsic (Cerasoli et al., 2014).

\subsection{Leadership}

Leadership is an important function for an organization. Carey, Phillppon, and Cummings (2011) suggested that leadership is a necessary for competitive advantage and success within a company. Effective leaders stem from having the ability to motivate employees (Dan-Shang \& Chia-Chun, 2013). The style of leadership and the strategies of a leader may determine the motivation of employees. In order to have success in a leadership position a leader must have the ability to solve problems as well as have critical thinking skills (De Meuse, Dai, \& Wu, 2011). Conversely, Limbare (2012) suggested that leadership is the ability to motivate individuals to use skills and resources to accomplish goals. The needs of the organization provide the varying definition of leadership. As business trends change, so does the type of leadership required for the change. Incorporating change within a company requires leadership (De Meuse et al., 2011). The common standard is that leadership and the strategies used by leaders is vital for organizational success.

Leadership behavior is a vital component for organizational success (Kawar, 2012). Research conducted by Nielson, Marrone, and Slay (2010) concluded that leaders have common behaviors, (a) dedication, (b) humility, and (c) empathy. These behaviors are important for an effective workforce. Although leadership behavior is important, understanding behaviors that leaders should not possess is also important. The research conducted by Nielson et al., (2010) failed to depict behaviors that leaders should not possess. Based on the expectancy theory, the behaviors of employees are just as important as the behaviors of leaders (Vroom, 1964).

The two common leadership styles are transformational and transactional. The way an individual motivates and influences others is leadership (Limbare, 2012). Transformational leadership is a style that has a positive impact on employee views as well as company goals (Wright, Moynihan, \& Pandey, 2012). Transformational leaders motivate subordinates to understand and support decisions of the leader (Sahaya, 2012). In contrast, transactional leadership style consists of rewarding workers for their performance (Sahaya, 2012). When leaders use this leadership style, leaders outline work requirements and rewards so employees understand what occurs when they achieve certain goals (Zhu, Sosik, Riggio, \& Yang, 2012). Since leaders use transactional leadership as a reward-based system, the effectiveness of this leadership style may become short-lived (Sahaya, 2012).

Leaders should have a clear vision with the ability to persuade subordinates to work towards achieving that vision (Birasnav, Rangneker, \& Dalpati, 2010). Additionally, Birasnav et al., (2010) determined through research that there is a direct relationship between leadership and company success. Transformational leaders create individual and team strength, which produce increased employee performance (Birasnav et al., 2010). Wright et al. (2012) determined that transformational leaders intrinsically motivate employees. Hoffman, Bynum, Piccolo, and Sutton (2011) determined that transformational leaders share the decision-making process and company objectives with employees. In the expectancy theory, leaders should share in the decision-making process as well as maintain a strong collaboration with employees (Vroom, 1964). Based on the decision theory, the ethics, principles, and behaviors of an individual determine their decisions (Scheibehenne et al., 2011). Since employees understand their needs and behaviors more than anyone else does, sharing the decision-making process with employees enhances performance and outcomes (Vroom, 1964).

\subsubsection{Strategies for leaders}

Company executives develop strategies to meet company goals. Strategies are critical for the sustainability of a business (Bonn \& Fisher, 2011). The strategies of an organization determine what resources to utilize as well as of the strategies showcase the vision and purpose of the business (Kalyani \& Sahoo, 2011). Strategy is a broad concept that requires leaders to think critically for the good of the entire organization. No matter the definition of strategy, strategy is important for competitive advantage.

Successful strategy begins with business leaders understanding the industry in which they work, the needs of the employees, and the resources of the company. Business leaders should ask questions in order to develop sound company strategies (Schmidt, 2009). The questions needed for executives to develop strategy are (a) what are the objectives, (b) what is the measure of success, and (c) how can the strategy be implemented (Schmidt, 2009). Strategy 
development is important to all businesses. The resource-based view (RBV) is a helpful method for business leaders to use for ascertaining the status and importance of strategies (Degravel, 2012).

Connecting strategies with company success could help business leaders with developing sound strategies for competitive advantage. The proper motivation of hiring managers should lead to effective hiring practices, which should result in having a productive workforce that aids with maintaining competitive advantage and lowering organizational costs (Poddar \& Madupalli, 2012).

\section{Decision Making}

The managerial decision-making process is vital to a business. The experiences of an individual aids with making decisions (Seo, Kun, \& Dae, 2013). During the decision-making process, several factors influence the decision-making process. Bell and Martin (2012) identified key factors within the decision-making process. These key factors include effective communication, training, and maintaining values aid with improving decisions. Bell and Martin (2012) concluded that managers should increase communication with employees as a means of making informed decisions on the job. When executives have the ability to motivate employees, this could increase communication with hiring managers.

\subsection{Decision field theory}

The values, experiences, and views of a person influences certain behaviors, which are important for the decision-making process (Hotaling, Busemeyer, \& Li, 2010). In addition, the decision field theory focuses on the way individuals focus their attentions to different parts of a problem in order to find additional results for any choices made (Hotaling et al., 2010). According to Scheibeheene, Rieskamp, \& Gonzalez-Vallejo, 2011) the decision field theory focuses on how individuals attempt to evaluate and make predictions for all the possible outcomes for a decision. Once an individual predicts an out for a decision, individuals attempt to identify which of the outcomes is most suitable for the problem (Scheibehenne et al., 2011). The decision field theory is a model used for describing the way individuals make decisions instead of a model for outline what individuals should do in order to make decisions (Hotaling et al., 2010). When making decisions, the normal thing to do is to choose an outcome with the least amount of resistance or the safer choice (Busemeyer \& Townsend, 2011).

Company employees rely on the expertise of management for daily operations. The basis of managerial expertise includes procedural and employee based decisions (Linna, Pekkola, Ukko, \& Melkas, 2009). A study conducted by Linna et al. (2009) outlined that when management allow experiences and bias to interfere with decisions made, company activities completed by employees suffer. Moreover, during the research process Linna et al. (2009) found that the effects of these actions cause employees to feel a lack of confidence about the decisions made by management. This disconnection between management and staff causes different opinions about job requirements and work ethic.

Research conducted by Grissom (2012) went a step further by determining that management should involve employees with decisions. Additionally, improper management decisions can increase employee turnover, absenteeism, and recruitment and training costs (Grissom, 2012). These increases affect the bottom line of a company. In addition to the company profits, von Siemens (2012) found through research that losing employees and lower production causes a decrease in competitive advantage. Reduced competitive advantage provides a means for the competition to gain a higher stake within the market thus, increasing the customer base (von Siemens, 2012). Furthermore, the researchers determined that the social preferences within a business impacts managerial decisions and impacts the bottom line of a company (von Siemens, 2012). This identifies the importance of managers making sound decisions because the goal of businesses is making profits and beating the competitors.

Working well with employees by identifying issues, opening communication are components of decision making for managers. While researching the effects on management decisions, the literature found provides elements of the judgment process. These elements include continued training for management, commitment for the success of the organization, and the ability to work with other members of management (Kalargyrou \& Woods, 2011). Managers that utilized the elements identified find success in terms of decision-making abilities.

\subsection{Decision-making strategies for hiring}

Recruitment is a strategy used by managers to obtain qualified employees. Recruiting new employees is costly, time consuming, and does not guarantee results (Ratna \& Chawla, 2012). Ratna and Chawla (2012) suggested that 
recruitment could cost a company $25 \%$ of the salary of a worker. Therefore, the methods used for recruiting is important to management in terms of managing cost and making an accurate employee selection (Ratna \& Chawla, 2012). Managers can utilize avenues such as, job placement ads in the newspaper, word of mouth, and the use of the company's website for gaining applicants for open positions. As technology changes, business professionals utilize social networking and Internet recruiting sites to find qualified applicants for positions and lower cost (Brencic \& Norris, 2012; Davison, Maraist, Hamiliton, \& Bing, 2012).

Utilizing these approaches could aid with increasing the amount of qualified applicants versus non-qualified applicants (Davison, Mariast, \& Bing, 2011). When using these avenues, managers should specify the requirements for the job position. Requirements for a position may include needed skills, educational achievement, and years of experience. Mueller and Baum (2011) suggested that company leaders use a job description as a means of identifying the requirements for a position. Utilizing this method not only limits the amount of applicants but aid managers with selecting individuals to screen (Mueller \& Baum, 2011). Conversely, simply reviewing an applicant's credentials on a website or job application may not aid with obtaining information on the applicants cognitive abilities. Davison et al. (2011) stated that companies might require the applicants to complete an exam or assessment for open job positions. Completing a form of an assessment aids with determining the skill level of an applicant. Jonsson and Rancano (2013) found that some assessments allow managers to estimate the performance abilities of potential workers.

In addition to assessments, managers search for individuals with degrees from colleges and/or universities with high grade point averages as a means of increasing the competitive advantage of the company (Tas \& Ergin, 2012). The goal of a company is to use these requirements to gain qualified applicants as well as provide management with a pool of individuals that could aid to the good of the company (Tas \& Ergin, 2012). In turn, utilizing recruitment procedures and job descriptions limits the preferences and/or inductive hiring by managers (Mueller \& Baum, 2011). Therefore, these procedures used by hiring professionals should aid with selecting employees. Elbanna and Naquib (2009) found that the guidelines set by leaders within a business should encourage deductive reasoning decisions by management instead of intuitive decisions based on beliefs and familiarity.

Managers select employees based on the needs of the company and work qualifications of the applicant. Gramm and Schnell (2013) suggested that the employment procedures and methods for the company could aid with attracting qualified workers. The practices include salaries, amount of employment security, training, and advancement opportunities (Gramm \& Schnell, 2013). Conversely, Chan and Kuok (2011) found that a proper hiring process aids with employee retention. The researchers suggested that company leaders review resumes, conduct interviews, and check references to select employees.

Once the recruitment process begins within an organization, managers review the resumes submitted by potential employees. These leaders choose individuals for interviewing or screening based on information within the applicants resume. Reviewing resumes provide organization leaders with the opportunity to gather details about the applicant. Rivera (2011) identified four additional classifications for the contents of resumes, which include scholastic achievements, job experience, and extracurricular activities. These classifications aid with making an impression to the person or persons reviewing the resume.

Further to the above-mentioned skills, previous researchers found that managers inquire about soft skills within the screening process (Robles, 2012). Soft skills include non-quantifiable elements such as a person's behavior, attitude, manners, and personality, which could determine possible strengths of applicants (Robles, 2012). Robles (2012) concluded that managers stated that many applicants lack soft skills.

A debate exists on utilizing references during the recruitment process. Previous researchers stated that hiring professionals find difficulty in checking references because of the possible legal issues that stem from negative references (Mueller \& Baum, 2011). In addition, because of the potential legal issues, Tews, Stafford and Tracey (2011) found that hiring professionals that request references assume that the applicant's references shall provide only positive feedback. Mueller and Baum (2011) suggested that only acquiring information from the former supervisors of applicants should aid with obtaining adequate information on applicants. Furthermore, Robles (2012) found that hiring professionals should inquire about the work ethic, time management, personality, and teamwork ability of applicants instead of hard skills.

Finding ideal candidates is a priority for managers. Managers utilize the resume as a means of screening potential workers during the recruitment process (Chan \& Khok, 2011). Huang, Huang, and Chiu (2011) questioned the effectiveness of the recruitment process. Using an adopted marketing strategy, the researchers examined if marketing aided with recruiting. Huang et al. (2011) discovered that managers should create marketing tactics that promote professional development throughout the recruitment process as a means of getting individuals to apply for job openings. 
The professional development tactics includes explaining the job description, benefits offered by the business, and ability to advance within the company. Effective recruitment processes aid with attracting qualified applicants (Huang et al., 2011).

During the recruitment process, managers attempt to select qualified individuals to fill open positions. Interviewing is a process used by managers to select employees (Sumanth \& Cable, 2011; Chan \& Kuok, 2011). Chan and Kuok (2011) found that managers might choose to conduct interviews via the telephone or in person. Phone interviews aid with gaining knowledge on job experience and the goals of the applicants. Chan and Kuok (2011) found that face-to-face interviews help managers determine if the applicant fits within the company culture. Sumanth and Cable (2011) found that managers utilize interviews to replace placement test because potential employees may not apply for positions that require testing. In an effort to question if the use of both interviews and placement tests help with gaining qualified employees than utilizing one method over the other, the researchers used a quasi-experimental design from a sample of 375 MBA alumni. The researchers discovered that individuals with experience perceive testing as unjust while those with limited experience perceived this process as fair. Therefore, utilizing both techniques could aid a firm with hiring employees but limit the amount of qualified applicants.

Although current researchers concluded that employers utilize interviews to hire workers, many hiring professionals lack interviewing skills. Due to this lack of interviewing skills, Camp, Schulz, Vielhaber, and Wagner-Marsh (2011) conducted an inquiry to question the perceptions of hiring professionals in terms of interviewing knowledge. In addition, the researchers questioned the perceptions of hiring professionals toward interview training. In essence, Camp et al. (2011) assumed that in order to hire qualified workers, hiring professionals should conduct interviews that aid with obtaining adequate information. A sample size of 122 hiring professionals answered survey questions. The study results indicated that $75 \%$ of the participants had interview experience and $34 \%$ of the respondents advocated for interview training. In addition, those participants that advocated for interview training believed that qualified applicants receive less job offers because hiring professionals lack interview skills.

Previous researchers indicate that interviewing skills aids with selecting qualified applicants (Camp et al., 2011). Other researchers Chan and Kuok (2011) stated that since selection process differ globally during the interview, managers should incorporate questions to determine if the applicant researched the organization, and understand the goals of the business. Another researcher Pomeroy (2012) suggested that hiring professionals utilize two interview techniques, which are technical questioning and scenario-based questioning. Technical questions aid with determining the skill set of an applicant. Scenario-based questioning aids with determining if the applicant has the ability to manage conflict, negotiate issues, and work with others. Using interviews could aid managers with hiring qualified employees.

During the hiring process, managers should attempt to hire for the long term. In other words, when looking for employees, managers should find good employees that fit within the organization and intend to stay with the company for an extended period of time (O'Connell et al., 2011). O'Connell et al. (2011) found that improper hiring of employees increases turnover rates both directly and indirectly for businesses. Direct costs include recruitment, salaries, benefits, and training (Sumanth \& Cable, 2011). Indirect costs include overtime pay for workers to complete tasks and decreased worker moral (McConnell, 2011). Conversely, (Rivera, 2012) determined that managers not only look for long term employees, managers search for workers that fit within the culture of the organization. Finding acceptance within the organization aids with fitting into the organization. Scholars examined the concept of social identity during hiring because the first few months of employment determines if a new employee will fit into and/or stay with the organization (O'Connell et al., 2011).

\subsection{Influences on decision making}

Outside factors influence the decisions of individuals in different ways (Marsh, 2013). Marsh (2013) found that the habits of a person influence decision making. Habits include the food eaten, method of dress, and work ethic. Marsh also suggested that habits could cause poor decision making especially when attempting to react correctly to situations involving others. In turn, the level of education and learning for a person influences the decisions of the individual (Marsh, 2013). Govaerts, Kyndt, Dochy, and Baert (2011) suggested that corporations should provide training and methods for increasing the knowledge of management and employees as a means of improving techniques, decision making, and policies. Improper policies and decision making could cause issues on the job, which include employee dissatisfaction, employee turnover, and lowered productivity (Kochanowski, 2011). Additionally, depending on the method in which individuals make decisions, the inability to lower the impact that outside factors have on the decision-making process could cause issues within a business. 
Other factors such as a person's specific skills or talents, and social background influence decisions. In terms of specific skills and talents, Govaerts et al. (2011) found that when an individual has expertise in specific areas, they perceive that no one has the ability to duplicate his or her efforts. Furthermore, this perception causes individuals to make the decision to overlook others that could effectively complete certain tasks. Conversely, Govaerts et al. suggested that a person with unique skills earns on the job respect, rewards, and receives recognition for efforts made by the company. The perception of having unique skills could aid with not sharing work responsibilities with others (Govaerts et al., 2011). In addition, the social background of a person influences decisions (Nielson \& Nielson, 2011). Some corporate leaders make decisions based on social backgrounds. Due to making decisions because of social backgrounds, on the international level managers are unable to interact with well-developed employees (Nielson \& Nielson, 2011). Therefore, the experiences of managers that lack a socially developed background and/or without an understanding of the background of others could cause them to make decisions without facts (Nielson \& Nielson, 2011).

In addition to skill set and social background, the mood and upbringing of a person influences decisions. When a person expresses a mood, that person can reflect this mood when making decisions (Hunter, 2012). Although individuals' social background influences decisions, people also view others based on upbringing (Nielson \& Nielson, 2011). Values placed on an individual stem from the home they lived in, neighborhood, family members, and work environment (Dahlgaard-Park, 2012). Hunter (2012) concluded that these values could cause bias within the decision-making process.

\section{Summary of the Literature Review}

The purpose of completing this short review offers information on the situation of hiring from affiliation to build and provide strategies for hiring managers to use proper decision making. To reflect the possible need for hiring strategies, multiple sources were reviewed to outline the connection between social identity theory and hiring. The review completed identified the connection between social identity theory and the perceptions of affiliations during the hiring process. Uziel (2010) determined that through impression management interviewees use cues to lead the perceptions of hiring managers. Using impression management to depict affiliations outlines a connection between social affiliation and hiring based on the perceptions of those affiliations. Therefore, these findings determine the need to fill the gap that may exist between social affiliation and the hiring of employees. This literature review of expectancy theory and decision making provides clarity of the importance of effective hiring within organizations.

\section{References}

Ashforth, B. E., \& Mael, F. (1989). Social identity theory and the organization. The Academy of Management Review, 14(1), 20-39. doi:10.2307/258189

Bell, R. L., \& Martin, J. S. (2012). The relevance of scientific management and equity theory in everyday managerial communication situations. Journal of Management Policy and Practice, 13(3), 106-115. Retrieved from http:// http://www.na-businesspress.com/

Birasnav, M., Rangnekar, S., \& Dalpati, A. (2010). Transformational leadership and human capital benefits: The role of knowledge management. Leadership \& Organization Development Journal, 32, 106-126. doi:10.1108/01437731111112962

Bonn, I., \& Fisher, J. (2011). Sustainability: The missing ingredient in strategy. The Journal of Business Strategy, 32(1), 5-14. doi:10.1108/02756661111100274

Brencic, V., \& Norris, J. B. (2012). Employers' on-line recruitment and screening practices. Economic Inquiry, 50(1), 94-111. doi:10.1111/j.1465-7295.2010.00324.x

Busemeyer, J. R., \& Townsend, J. T. (2011). Decision field theory: A dynamic-cognitive approach to decision making in an uncertain environment. Psychological Review, 94(4), 332-360. doi:20.1036/0023-295X.100.3.449

Cadwallader, S., Jarvis, C. B., Bitner, M. J., \& Ostrom, A. L. (2010). Frontline employee motivation to participate in service innovation implementation. Journal of the Academy of Marketing Science, 38, 219-239. doi:10.1007/s11747-009-0151-3

Camp, R. R., Schulz, E., Vielhaber, M. E., \& Wagner-Marsh, F. (2011). Human resource professionals' perceptions of interviewer training. Journal of Managerial Issues, 23, 250-268. Retrieved from http://www.pittstate.edu/department/economics/journal-ofmanagerial-issues/

Carey, W., Philippon, D. J., \& Cummings, G. G. (2011). Coaching models for leadership development: An integrative review. Journal of Leadership Studies, 5(1), 51-69. doi:10.1002/jls.20204

Cerasoli, C. P., Nicklin, J. M., \& Ford, M. T. (2014). Intrinsic motivation and extrinsic incentives jointly predict performance: A 40-year meta-analysis. Psychological Bulletin, 140, 980-1008. doi:10.1037/a0035661

Chan, S., \& Kuok, O. (2011). A study of human resources recruitment, selection, and retention issues in the hospitality and tourism industry in Macau. Journal of Human Resources In Hospitality \& Tourism, 10, 421-441. doi:10.1080/15332845.2011.588579

Culkin, N., \& Mallick, S. (2011). Producing work-ready graduates: The role of the entrepreneurial university. International Journal of Market Research, 53, 347-368. Retrieved from http://www.ijmr.com 
Dahlgaard-Park, S. (2012). Core values - the entrance to human satisfaction and commitment. Total Quality Management \& Business Excellence, 23(2), 125-140. doi:10.1080/14783363.2012.655067

Dan-Shang, W., \& Chia-Chun, H. (2013). The effect of authentic leadership on employee trust and employee engagement. Social Behavior \& Personality: An International Journal, 41, 613-624. doi:10.224/sbp.2013.41.4.613

Davison, H. K., Maraist, C., \& Bing, M. N. (2011). Friend or foe? The promise and pitfalls of using social networking sites for HR decisions. Journal Business Psychology, 26, 153-159. doi:10.1007/s10869-011-9215-8

Davison, H. K., Maraist, C. C., Hamilton, R. H., \& Bing, M. N. (2012). To screen or not to screen? Using the internet for selection decisions. Employee Responsibilities and Rights Journal, 24(1), 1-21. doi:10.1007/s10672-011-9178-y

Degravel, D. (2012). Strategy-as-practice to reconcile small businesses strategies and RBV? Journal of Management Policy and Practice, 13, 46-66. Retrieved from http://www.na-businesspress.com/jmppopen.html

De Meuse, K. P., Dai, G., \& Wu, J. (2011). Leadership skills across organizational levels: A closer examination. The PsychologistManager Journal, 14(2), 120-139. doi:10.1080/10887156.2011.570143

Dysvik, A., \& Kuvaas, B. (2013). Intrinsic and extrinsic motivation as predictors of work effort: The moderating role of achievement goals. British Journal of Social Psychology, 52, 412-430. doi:10.1111/j.2044-8309.2011.02090.x

Elbanna, S., \& Naguib, R. (2009). How much does performance matter in strategic decision making? International Journal of Productivity and Performance Management, 58, 437-459. doi:10.1108/17410400910965715

Fischer, M. J. (2010). Can institutional networks mitigate labor market disadvantages? Evidence from college summer job searches. Social Science Quarterly, 91, 1264-1287. doi:10.1111/j.1540-6237.2010.00731.x

Fitzsimmons, J. R., \& Douglas, E. J. (2011). Interaction between feasibility and desirability in the formation of entrepreneurial intentions. Journal of Business Venturing, 26(4), 431-440. doi:10.1016/j.jbusvent.2010.01.001

Govaerts, N., Kyndt, E., Dochy, F., \& Baert, H. (2011). Influence of learning and working climate on the retention of talented employees. Journal of Workplace Learning, 23(1), 35-55. doi:10.1108/13665621111097245

Gramm, C. L., \& Schnell, J. F. (2013). Does employment security influence organizational hiring success? International Journal of Business and Social Science, 4(3), 23-32. Retrieved from http://www.ijbssnet.com

Grissom, J. A. (2012). Revisiting the impact of participative decision making on public employee retention the moderating influence of effective managers. The American Review of Public Administration, 42, 400-418. doi:10.1177/0275074011404209

Hewapathirana, G. I. (2011). The role of social identity in internationalization of women-owned small business in Sri Lanka, Journal of Asia Business Studies, 5, 172-193. doi:10.1108/1558789111152339

Hoffman, B. J., Bynum, B. H., Piccolo, R. F., \& Sutton, A. W. (2011). Person-organization value congruence: How transformational leaders influence work group effectiveness. Academy of Management Journal, 54, 779-796. doi:10.5465/AMJ.2011.64870139

Hotaling, J. M., Busemeyer, J. R., \& Li, J. (2010). Theoretical developments in decision field theory: Comment on Tsetsos, Usher, and Chater (2010). Psychological Review, 117, 1294-1298. doi:10.1037/a0020401

Huang, W. H. D., Huang, W. Y., \& Chiu, C. C. (2011). The impact of specified professional development programme information as a marketing tool for effective recruitment. Human Resource Development International, 14(1), 57-73.doi:10.1080/13678868. 2011.542898

Hunter, M. (2012). How motivation really works: Towards an emoto-motivation paradigm. Economic, Management, and Financial Markets, 7, 138-196. Retrieved from http://www.addletonacadeicpublishers.com/editorial-board/journal

Jalbert, T., Furumo, K., \& Jalbert, M. (2011). Does educational background affect CEO compensation and firm performance? Journal of Applied Business Research, 27(1), 15-39. Retrieved from http://journals.cluteonline.com/index.php/JABR

Jonsson, J. E. \& Rancano, A. (2013). Hiring employees that fit with a proactive approach. International Journal of Business and Social Science, 4, 106-114. Retrieved from http://www.ijbssnet.com

Kalargyrou, V., \& Woods, R. H. (2011). Wanted: Training competencies for the twenty-first century. International Journal of Contemporary Hospitality Management, 23, 361-376. doi:10.1108/09596111111122532

Kalyani, M., \& Sahoo, M. P. (2011). Human resource strategy: A tool of managing change for organizational excellence. International Journal of Business and Management, 6(8), 280-286. doi:10.5539/ijbm.v6n8p280

Kawar, T. (2012). The impact of leadership on student learning. International Journal of Business \& Social Science, 3, 319-322. Retrieved from http://ijbssnet.com

Khan, S. (2013). Viewpoint what college could be like: Imagining an optimized education model. Communications of the ACM, 56(1), 4143. doi:10.1145/2398356.2398370

Khan, N. S., Riaz, A., \& Rashid, M. (2011). The impact of work content, working conditions, career growth on employee motivation. Interdisciplinary Journal of Contemporary Research in Business, 3, 1428-1443. Retrieved from http://www.jjerb.webs.com/

Kleinmann, M., \& Klehe, U. C. (2011). Selling oneself: Construct and criterion-related validity of impression management in structured interviews. Human Performance, 24(1), 29-46. doi:10.1080/08959285.2010.530634

Kochanowski, Y. J. (2011). Human capital management in government: Replacing government retirees. Journal of Health and Human Services Administration, 34(1), 85-108. Retrieved from http://www.spaef.com/jhhsa.php

Korzynski, P. (2013). Employee motivation in new working environment. International Journal of Academic Research, 5, $184-188$. doi:10.7813/2075-4124.2013/5-5/B.28

Leary, M. R., \& Kowalski, R. M. (1990). Impression management: A literature review and two-component model. Psychological Bulletin, 107(1), 34-47. doi:10.1037/0033-2909.107.1.34

Liao, H. L., Liu, S. H., \& Pi, S. M. (2011). Modeling motivations for blogging: An expectancy theory analysis. Social Behavior and 
Personality: An International Journal, 39(2), 251-264. doi:10.2224/sbp.2011.39.2.251

Limbare, S. (2012). Leadership styles \& conflict management styles of executives. Indian Journal of Industrial Relations, 48, 172-180. Retrieved from http://www.srcirhr.com/ijir.php

Linna, P. Pekkola, S., Ukko, J., \& Melkas, H. (2009). Defining and measuring productivity in the public sector: Managerial perceptions. International Journal of Public Sector, 23, 479-499. doi:10.1108/09513551011058493

Liu, W., Friedman, R., \& Hong, Y. Y. (2012). Culture and accountability in negotiation: Recognizing the importance of in-group relations. Organizational Behavior and Human Decision Processes, 117, 221-234. oi:10.1016/j.obhdp.2011.11.001

Lunenburg, F. C. (2011). Expectancy theory of motivation: Motivating by altering expectations. International Journal of Management, Business, and Administration, 15(1), 1-6. Retrieved from https://www.academeresearchjournals.org/journal/ijbma

Marin, L., \& Ruiz de Maya, S. (2013). The role of affiliation, attractiveness and personal connection in consumer-company identification. European Journal of Marketing, 47, 655-673. doi:10.1108/03090561311297526

Marsh, C. (2013). Business executives' perceptions of ethical leadership and its development. Journal Business Ethics, 114, 565-582. doi:10.1007/s10551-012-1366-7

Maslow, A. H. (1943). A theory of human motivation. Psychological Review, 50, 370-396. doi:10.1037/h0054346

McConnell, C. R. (2011). Addressing employee turnover and retention: Keeping your valued performers. The Health Care Manager, 30(3), 271-283. doi:10.1097/HCM.0b013e318225e3bf

Mueller, J. R., \& Baum, B. (2011). The definitive guide to hiring right. Journal of Applied Business and Economics, 12, 140-153. Retrieved from http://www.na-businesspress.com

Nagy, B., Kacmar, M., Harris, K. (2011). Dispositional and situational factors as predictors of impression management behaviors. Journal of Behavioral and Applied Management, 12(3), 229-245. Retrieved from http://www.ibam.com/pubs/jbam/

Nawab, S., Bhatti, K. K., \& Shafi, K. (2011). Effect of motivation on employees performance. Interdisciplinary Journal of Contemporary Research in Business, 3, 1209-1216. Retrieved from http://www.ijcrb.webs.com/

Nielsen, R., Marrone, J. A., \& Slay, H. S. (2010). A new look at humility: Exploring the humility concept and its role in socialized charismatic leadership. Journal of Leadership \& Organizational Studies, 17, 33-43. doi:10.1177/1548051809350892

Nielsen, B. B., \& Nielsen, S. (2011). The role of top management team international orientation in international strategic decision-making: The choice of foreign entry mode. Journal of World Business, 46(2), 185-193. doi:10.1016/j.jwb.2010.05.003

O'Connell, M. S., Kung, M. C., \& Tristan, E. (2011). Beyond impression management: Evaluating three measures of response distortion and their relationship to job performance. International Journal of Selection and Assessment, 19, 340-351. doi:10.1111/j.14682389.2011.00563.x

Oyewobi, L. O., Suleiman, B., \& Muhammad-Jamil, A. (2012). Job satisfaction and job commitment: A study of quantity surveyors in Nigerian public service. International Journal of Business and Management, 7, 179-192. doi:10.5539/ijbm.v7n5p179

Pierce, W. D., Cameron, J., Banko, K. M., \& So, S. (2012). Positive effects of rewards and performance standards on intrinsic motivation. The Psychological Record, 53(4), 4. Retrieved from http://opensiuc.lib.siu.edu/tpr/vo153/iss4/4

Poddar, A., \& Madupalli, R. (2012). Problematic customers and turnover intentions of customer service employees. The Journal of Services Marketing, 26, 551-559. doi:10.1108/08876041211266512

Pomeroy, J. (2012). Straight to the core. The Safety \& Health Practitioner, 30(2), 32-35. Retrieved from http://www.shponline.co.uk

Ratna, R., \& Chawla, S. (2012). Key factors of retention and retention strategies in telecom sector. Sona Global Management Review, 6(3), 35-46. Retrieved from http://www.sonamgmt.org

Renko, M., Kroeck, K. G., \& Bullough, A. (2012). Expectancy theory and nascent entrepreneurship. Small Business Economics, 39, 667684. doi:10.1007/s11187-011-9354-3

Rivera, L. A. (2011). Ivies, extracurriculars, and exclusion: Elite employers' use of educational credentials. Research in Social Stratification and Mobility, 29(1), 71-90. doi:10.1016/j.rssm.2010.12.001

Rivera, L. A. (2012). Hiring as cultural matching: The case of elite professional service firms. American Sociological Review, 77, 9991022. doi:10.1177/0003122412463213

Robles, M. M. (2012). Executive perceptions of the top 10 soft skills needed in today's workplace. Business Communication Quarterly, 75, 453-465. doi:10.1177/1080569912460400

Sahaya, N. (2012). A learning organization as a mediator of leadership style and firms' financial performance. International Journal of Business \& Management, 7, 96-113. doi:10.5539/ijbm.v7n14p96

Scheibehenne, B., Rieskamp, J., \& \& Gonzalez-Vallejo, C. (2011). Cognitive models of choice: Comparing decision field theory to the proportional difference model. Cognitive Science: A Multidisciplinary Journal, 33(5), 911-939. Retrieved from http://cognitive sciencesociety.org/journal.html

Schmidt, T. (2009). Strategic project management made simple. Hoboken, NJ: John Wiley \& Sons.

Seo, Y. W., Kun, C. L., \& Dae, S. L. (2013). The impact of ubiquitous decision support systems on decision quality through individual absorptive capacity and perceived usefulness. Online Information Review, 37, 101-113. doi:10.1108/14684521311311658

Smith, L. G. E., Amiot, C. E., Callan, V. J., Terry, D. J., \& Smith, J. R. (2012). Getting new staff to stay: The mediating role of organizational identification. British Journal of Management, 23(1), 45-64. doi:10.1111/j.1467-8551.2010.00728.x

Sumanth, J. J., \& Cable, D. M. (2011). Status and organizational entry: How organizational and individual status affect justice perceptions of hiring systems. Personnel Psychology, 64, 963-1000. doi:10.1111/j.1744-6570.2011.01233.x

Tajfel, H. (1979). Individuals and groups in social psychology. British Journal of Social and Clinical Psychology, 18, $183-190$. doi:10.111/j.2004-8260.1979.tb00324.x 
Tajfel, H., \& Turner, J. C. (1986). The social identity theory of inter-group behavior. Chicago, IL: Nelson-Hall.

Tas, A., \& Ergin, E. A. (2012). Key factors for student recruitment: The issue of university branding. International Business Research, 5 , 146-153. doi:10.5539/ibr.v5n10p146

Tews, M. J., Stafford, K., \& Tracey, J. B. (2011). What matters most? The perceived importance of ability and personality for hiring decisions. Cornell Hospitality Quarterly, 52(2), 94-101. doi:10.1177/1938965510363377

Uziel, L. (2010). Rethinking social desirability scales: From impression management to interpersonally oriented self-control. Perspectives on Psychological Science, 5, 243-262. doi:10.1177/1745691610369465

Vallerand, R. J.. (2012). From motivation to passion: In search of the motivational processes involved in a meaningful life. Canadian Psychology, 53(1), 42-52. doi:10.1037/a0026377

von Siemens, F. A. (2012). Social Preferences, Sorting, and Competition. Scandinavian Journal Of Economics, 114, $780-807$. doi:10.1111/j.1467-9442.2012.01713.x

Vroom, V. (1964). Work and motivation. San Francisco, CA: Jossey-Bass.

Walumbwa, F. O., Mayer, D. M., Wang, P., Wang, H., Workman, K., \& Christensen, A. L. (2011). Linking ethical leadership to employee performance: The roles of leader-member exchange, self-efficacy, and organizational identification. Organizational Behavior and Human Decision Processes, 115(2), 204-213. doi:10.1016/j.obhdp.2010.11.002

Wright, B. E., Moynihan, D. P., \& Pandey, S. K. (2012). Pulling the levers: Transformational leadership, public service motivation, and mission valence. Public Administration Review, 72(2), 206-215. doi:10.1111/j.1540-6210.2011.02496.x

Zhu, W., Sosik, J. J., Riggio, R. E., \& Yang, B. (2012). Relationships between transformational and active transactional leadership and followers' organizational identification: The role of psychological empowerment. Journal of Behavioral \& Applied Management, 13, 186-212. Retrieved from http://www.ibam.com/pubs/jbam/ 